\title{
Estrogen receptor and progesterone receptor are prognostic factors in soft tissue sarcomas
}

\author{
ANDREJ VALKOV ${ }^{1,3}$, SVEINUNG SORBYE ${ }^{1,3}$, THOMAS K. KILVAER ${ }^{3}$, TOM DONNEM ${ }^{2,4}$, \\ EIVIND SMELAND ${ }^{2}$, ROY M. BREMNES ${ }^{2,4}$ and LILL-TOVE BUSUND ${ }^{1,3}$
}

\begin{abstract}
Departments of ${ }^{1}$ Clinical Pathology and ${ }^{2}$ Oncology, University Hospital of Northern Norway; Institutes of ${ }^{3}$ Medical Biology and ${ }^{4}$ Clinical Medicine, University of Troms $\varnothing$, Troms $\varnothing$, Norway
\end{abstract}

Received November 16, 2010; Accepted December 29, 2010

DOI: $10.3892 /$ ijo.2011.920

\begin{abstract}
Estrogen (ER) and progesterone receptor (PgR) regulate growth and cell differentiation upon ligand-dependent and ligand-independent activation. In breast cancer and gynecological tumors their expression are known predictors of endocrine therapy benefits and a favourable therapyindependent prognosis. In soft tissue sarcomas, their expression profile is poorly defined and their significance is uncertain. We investigated the prognostic impact of ER and PgR in non-gastrointestinal stromal tumor soft tissue sarcomas (non-GIST STSs). Tumor samples and clinical data from 249 patients with non-GIST STS were obtained, and tissue microarrays (TMAs) were constructed for each specimen. Immunohistochemistry (IHC) was used to evaluate marker expression in tumor cells. In univariate analyses, the expression of neither ER nor $\mathrm{PgR}(\mathrm{P}=0.333$ and 0.067 , respectively) were significant prognosticators in the total cohort. However, measured separately for each gender, ER positivity was a significant favourable indicator for disease specific survival (DSS) in women $(\mathrm{P}=0.017)$ while $\mathrm{PgR}$ positivity had inverse impact in men $(\mathrm{P}=0.001)$. Among the four possible coexpression profiles, $\mathrm{ER}^{-} / \mathrm{PgR}^{+}$was significantly least favourable for survival in the univariate analysis $(\mathrm{P}<0.001)$. In the multivariate analysis, the $\mathrm{ER}^{-} / \mathrm{PgR}^{+}$phenotype was an independent negative prognostic factor for DSS $(\mathrm{HR}=1.9,95 \% \mathrm{CI}=1.2-3.1, \mathrm{P}=0.008)$ in addition to patient's nationality, tumor depth, histological entity, malignancy grade, metastasis at diagnosis, surgery and positive resection margins. The present findings indicate that ER and PgR have significant gender dependent impact on DSS in non-GIST STSs.
\end{abstract}

\section{Introduction}

Soft tissue sarcomas (STS) are malignant tumors arising from extraskeletal mesenchymal tissues. They are heterogeneous neoplasms, consisting of more than 50 subtypes, but comprise

Correspondence to: Dr Andrej Valkov, Dept. of Clinical Pathology, University Hospital of Northern Norway, 9038 Troms $\varnothing$, Norway

E-mail: andrej.yurjevic.valkov@unn.no

Key words: soft tissue sarcomas, estrogen receptor, progesterone receptor, disease-specific survival only $0.5 \%$ of adult malignancies (1). Approximately $50 \%$ of the STS patients will succumb to their disease because of metastasis or local relapse (2). The prognostic factors determining tumor progression and ultimately the patients' fate include tumor grade, size, location, depth, histological entity, positive resection margins and presence of local recurrence (3-9).

We have recently shown (unpublished data) that transforming growth factor-beta 1 (TGF- $\beta 1$ ) is a strongly independent negative prognostic marker in women in separate uni- and multivariate analyses, but not significant in men. This prompted us to investigate whether expression of the sex-related steroid hormone receptors, ER and PgR, could have prognostic impact on STS associated DSS.

ER is a group of receptors activated by the hormone $17 \beta$-estradiol (estrogen). There are two separate, but highly homologous isoforms of ER, ER $\alpha$ and ER $\beta$, which have completely different tissue distribution (10). They are encoded by two separate genes, ESR1 and ESR2, respectively. Like $\mathrm{ER}, \mathrm{PgR}$ protein exists as two receptor isoforms, called in this case $A$ and $B$, but these are product of the same gene.

$\mathrm{ER}$, mostly in $\alpha$ isoform, mediates the action of estrogens and is responsible for growth and differentiation of target cells. $\mathrm{PgR}$ is considered as the ER's antagonist. However, selective ablation of PgR-A in a mouse model, resulted in exclusive production of PgR-B indicating that PR-B contributes to, rather than inhibits, epithelial cell proliferation both in response to estrogen alone and in the presence of progesterone (11).

Both ER and, to a lesser degree, PgR are well known prognosticators of endocrine therapy success in breast cancer $(12,13)$. They are also shown to have a slight positive prognostic effect irrelative of endocrine therapy (14). However, their expression in STSs, especially those outside the gynaecological sphere, is scarcely investigated. Moreover, the prognostic value of such expression still remains unknown.

In this study, we investigate the prognostic impact of ER and PgR in 249 non-GIST STS patients. To our knowledge this is the first prognostic evaluation of these biomarkers in non-GIST STSs.

\section{Patients and methods}

Patients and clinical samples. Primary tumor tissue from anonymized patients diagnosed with non-GIST STS at the 
University Hospital of Northern Norway (UNN) 1973-2006 and The Hospitals of Arkhangelsk region, Russia, were used in this retrospective study. In total, 496 patients were registered from the hospital databases. Of these, 247 patients were excluded due to missing clinical data $(\mathrm{n}=86)$ or inadequate material for histological examination $(\mathrm{n}=161)$. Thus, 249 STS patients with full clinical records and adequate paraffin-embedded tissue blocks were eligible.

This report includes follow-up data as of September 2009. The median follow-up was 38 months (range 0.1-392). Formalinfixed and paraffin-embedded tumor specimens were obtained from the archives of the Departments of Pathology at UNN and the Arkhangelsk hospitals. The tumors were graded according to the French Fèdèration Nationales des Centres de Lutte Contre le Cancer (FNCLCC) (15).

Microarray construction. All sarcomas were histologically reviewed by two trained pathologists (Sveinung Sorbye and Andrej Valkov) and the most representative areas of viable tumor cells (neoplastic cells) were carefully selected and marked on the hematoxylin and eosin (HE) slides and sampled for the tissue microarray blocks (TMAs). The TMAs were assembled using a tissue-arraying instrument (Beecher Instruments, Silver Springs, MD). The Detailed methodology has been previously reported (16). Briefly, we used a 0.6-mm diameter stylet, and the study specimens were routinely sampled with two replicate core samples (different areas) of neoplastic tissue. To include all core samples, 12 tissue array blocks were constructed. Multiple 4- $\mu \mathrm{m}$ sections were cut with a Micron microtome (HM355S) and stained by specific antibodies for immunohistochemistry (IHC) analyses.

Immunohistochemistry $(I H C)$. The applied antibodies were subjected to in-house validation by the manufacturer for IHC analysis on paraffin-embedded material. Estrogen (ER $\alpha)$ receptor (mouse monoclonal; SP1; Ventana Medical Systems; prediluted) and progesterone (PgRA+PgRB) receptor (rabbit monoclonal; 1E2; Ventana Medical Systems; prediluted).

Sections $(4 \mu \mathrm{m})$ were deparaffinized with EZ prep at $75^{\circ} \mathrm{C}$ and stained using Ventana Benchmark XT (Ventana Medical Systems Inc.), procedure iViewDAB. Antigen retrieval was CC1 mild for PgR and CC1 standard for ER. Primary antibodies against $\mathrm{ER}$ and $\mathrm{PgR}$ were incubated at $37^{\circ} \mathrm{C}$ for $32 \mathrm{~min}$ for $\mathrm{ER}$ and $24 \mathrm{~min}$ for PgR. As secondary antibodies biotinylated goat anti-mouse IgG and IgM and goat anti-rabbit IgG were used for, correspondingly, SP1 and 1E2. This was followed by application of liquid diaminobenzidine and substratechromogen, yielding a brown reaction product at the site of the target antigen (iView DAB ${ }^{\circledR}$ procedure). Finally, slides were counterstained with hematoxylin to visualize the nuclei. For each antibody, include negative controls, all TMA staining were performed in a single experiment.

Scoring of IHC. The ARIOL imaging system (Genetix, San Jose, CA) was used to scan the slides with immunohistochemically stained TMAs. The specimens were scanned at a low resolution (1.25x) and high resolution (20x) using Olympus BX 61 microscope with an automated platform (Prior). The slides were loaded in the automated slide loader (Applied Imaging SL 50). Representative and viable tissue sections were scored semiquantitatively on the computer screen for nuclear staining. To measure the grade of staining, we adapted the Allred Score (17) system for STS as shown (Table I). Examples of scoring assessment are shown in Fig. 1. All samples were anonymized and independently scored by two pathologists (A. Valkov and S. Sorbye). In case where score difference was exceeding 1 , the slides were re-examined and a consensus was reached by the observers. When assessing a score for a given core, the observers were blinded to the scores of the other variables and to outcome. Mean score for duplicate cores from each individual was calculated.

Statistical methods. All statistical analyses were done using the statistical package SPSS (Chicago, IL), version 16. The IHC scores from each observer were compared for interobserver reliability by use of a two-way random effect model with absolute agreement definition. The intraclass correlation coefficient (reliability coefficient) was obtained from these results. The $\chi^{2}$ test and Fisher's exact test were used to examine the association between molecular marker expression and various clinicopathological parameters. Univariate analyses were done by using the Kaplan-Meier method, and statistical significance between survival curves was assessed by the log-rank test. Disease-specific survival (DSS) was determined from the date of histological confirmed STS diagnosis to the time of STS death. To assess the independent value of different pretreatment variables on survival, in the presence of other variables, a multivariate analysis was performed using the Cox proportional hazards model. Only variables of significant value from the univariate analysis were entered into the Cox regression analysis. Probability for stepwise entry and removal was set at 0.05 and 0.10 , respectively. The significance level used was $\mathrm{P}<0.05$.

Ethical clearance. The National Cancer Data Inspection Board and The Regional Committee for Research Ethics approved the study.

\section{Results}

Clinicopathological variables. The clinicopathological variables are summarized in Table II. Median age was 59 (range, 0-91) years and 56\% were female. The non-GIST STS comprised 249 tumors including undifferentiated pleomorphic sarcoma $(\mathrm{n}=68)$, leiomyosarcoma $(\mathrm{n}=67)$, liposarcoma $(\mathrm{n}=34)$, malignant fibroblastic/myofibroblastictumors $(\mathrm{n}=20)$, rhabdomyosarcoma $(n=16)$, synovial sarcoma $(n=16)$, angiosarcoma $(n=13)$, malignant peripheral nerve sheath tumor (MPNST) $(n=11)$ and other types of sarcoma $(n=4)$. The tumors were localized in the extremities $(n=89)$, trunk $(n=47)$, retroperitoneum $(n=37)$, head/neck $(n=18)$ and viscera $(n=58)$. The first line treatment modality was surgery $(\mathrm{n}=228), 120$ patients received surgery alone, 55 patients received surgery and radiotherapy, 40 patients received surgery and chemotherapy, 13 patients received surgery, radiotherapy and chemotherapy. Of the 21 non-operated patients (inoperable, $\mathrm{n}=11$; advanced age/other serious disease, $n=5$, STS diagnosis confirmed post mortem, $n=3$; patient refusal, $n=2$ ) seven received chemotherapy and/or radiotherapy. Fourteen patients did not obtain any treatment. 
Table I. Modified Allred score system, adapted for STS showing score 0-3 related to staining intensity and percent positive cells.

\begin{tabular}{lcccc}
\hline & \multicolumn{4}{c}{$\%$ positivity } \\
\cline { 2 - 5 } Intensity & $<1 \%$ & $1-10 \%$ & $11-33 \%$ & $34 \%$ and more \\
\hline Weak & 0 & 0 & 1 & 2 \\
Moderate & 0 & 1 & 2 & 3 \\
and strong & & & & \\
\hline
\end{tabular}

Interobserver variability. Interobserver scoring agreement was tested for both markers. The intraclass correlation coefficients were 0.92 for ER $(\mathrm{P}<0.001)$ and 0.96 for $\mathrm{PgR}(\mathrm{P}<0.001)$.

Expression pattern and correlations with clinicopathological variables. The ER and PgR demonstrated nuclear positivity in tumor cells and the positivity threshold was taken as $1 \%$ for both ER and PgR (Table I). The most intensively ER- and PgR-positive tumors were leiomyosarcomas in the uterus. However, the moderately and especially weakly positive tumors were distributed relatively equally between genders and histological entities (Table III).

The expressions of ER and PgR correlated strongly with each other. Among the PgR-positive tumors, 53\% were also ER-positive, while $32 \%$ of PgR-negative tumors showed some grade of ER-expression $(\mathrm{r}=0.206, \mathrm{P}=0.002)$. Fifty-three percent of STSs expressed at least one of the steroid hormone receptors.

Women had PgR-positive tumors significantly more often than men $(\mathrm{P}=0.025)$, and STSs of younger patients $(<60)$ expressed $\mathrm{PgR}$ more frequently compared to the older age group, 37 and $24 \%(\mathrm{P}=0.008)$ respectively. No such relations were seen for ER expression.
ER expression correlated significantly with STS location and size. While visceral tumors expressed ER in $50 \%$ of cases, the tumors located on extremities did so in $30 \%$ and retroperitoneal STS in $24 \%(\mathrm{P}=0.008)$. Further, tumors $<5 \mathrm{~cm}$ in diameter were ER-positive in $52 \%$, while larger tumors showed ER-positivity in $33 \%(\mathrm{P}=0.007)$. None of the steroid hormone receptors correlated significantly with histological diagnosis, tumor depth, grade of malignancy, or distant relapse rate.

Univariate analyses. Data are presented in Table II. Patient nationality $(\mathrm{P}=0.011)$, tumor size $(\mathrm{P}=0.027)$, histological grade $(\mathrm{P}<0.001)$, tumor depth $(\mathrm{P}<0.001)$, metastasis at time of diagnosis $(\mathrm{P}<0.001)$, surgery $(\mathrm{P}<0.001)$ and resection margins $(\mathrm{P}<0.001)$ were all significant prognostic variables for DSS

As shown in Table IV, ER and PgR showed no prognostic impacts on DSS by analysing the whole cohort. However, separate analyses of each gender revealed that ER expression was a significant positive prognostic factor in women $(\mathrm{P}=0.017)$, while PgR expression was associated with a poor prognosis in men $(\mathrm{P}=0.001)$. Moreover, ER positivity in men and women tended towards opposite prognostic effects as shown in Fig. 2A and B. Among the four possible coexpression patterns of $\mathrm{ER}$ and $\mathrm{PgR}$, the $\mathrm{ER}^{-} / \mathrm{PgR}^{+}$profile for the whole cohort, which was seen in $14 \%$ of the patients $(n=34)$, was associated with a dismal prognosis $(\mathrm{P}<0.001)$ (Fig. 2E).

Multivariate Cox proportional hazards analyses. Only variables which were significant in univariate analyses were entered into the multivariate analysis, which was carried out for all patients and separately for men and women (Table V). Neither ER nor PgR expression influenced significantly on prognosis alone taken in the Cox regression analysis. However, ER $/$ $\mathrm{PgR}^{+}$phenotype was an independent negative prognostic factor for DSS ( $\mathrm{HR}=1.9,95 \% \mathrm{CI}=1.2-3.1, \mathrm{P}=0.008)$ in addition to tumor depth, malignancy grade, metastasis at diagnosis, presence of surgery and positive resection margins.
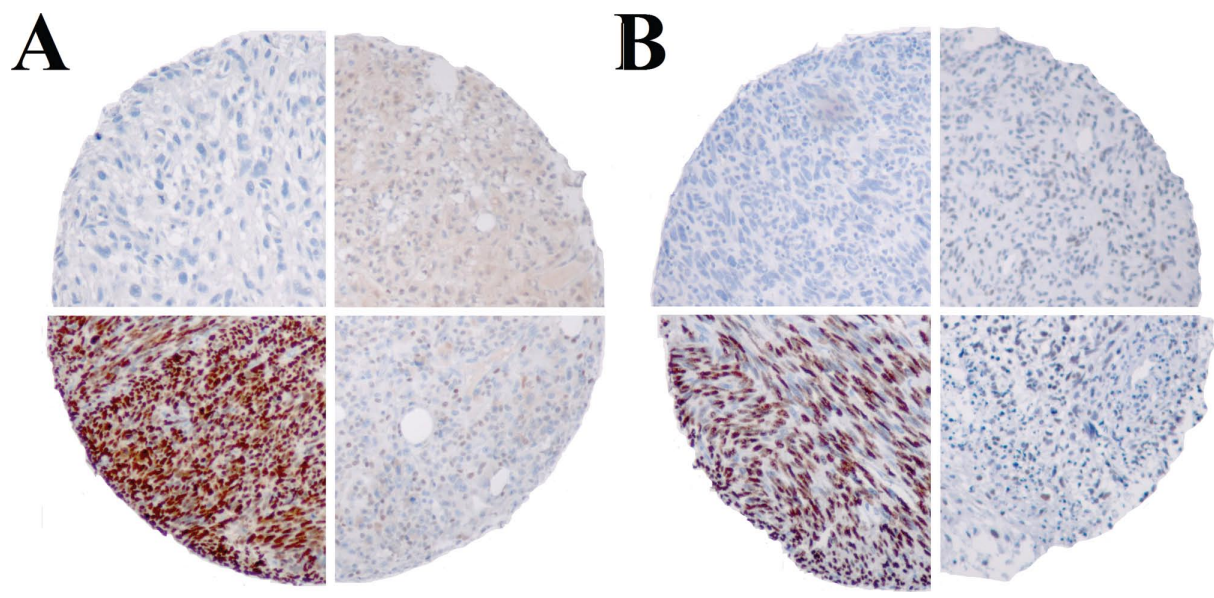

Figure 1. IHC analysis of TMA of non-GIST STS representing different scores of tumor cell expression of ER and PgR. (A) Upper left quadrant, AS, ER, negative staining, score 0; upper right quadrant, LS, ER, weak staining, score 1; lower right quadrant, CCS, ER, moderate staining, score 2; lower left quadrant, LMS, ER, strong staining, score 3. (B) Upper left quadrant, MPNST, PgR, negative staining, score 0; upper right quadrant, LS, PgR, weak staining, score 1; lower right quadrant, UPS, PgR, moderate staining, score 2; lower left quadrant, LMS, PgR, strong staining, score 3. IHC, immunohistochemistry; TMA, tissue microarray; non-GIST STS, non gastrointestinal stromal tumor soft-tissue sarcoma; ER, estrogen receptor; PgR, progesterone receptor; AS, angiosarcoma; LS, liposarcoma; CCS, clear cell sarcoma; LMS, leiomyosarcoma; MPNST, malignant peripheral nerve sheath tumor; UPS, undifferentiated pleomorphic sarcoma. 
Table II. Prognostic clinicopathological variables as predictors for disease-specific survival (univariate analyses, log-rank test) in 249 non-GIST STSs, for all patients and separately for men and women.

\begin{tabular}{|c|c|c|c|c|c|c|c|c|c|c|c|c|}
\hline \multirow[b]{2}{*}{ Characteristic } & \multicolumn{3}{|c|}{ Patients, n (\%) } & \multicolumn{3}{|c|}{$\begin{array}{c}\text { Median survival } \\
\text { (months) }\end{array}$} & \multicolumn{3}{|c|}{$\begin{array}{c}\text { 5-year survival } \\
(\%)\end{array}$} & \multicolumn{3}{|c|}{ P-value } \\
\hline & A & M & $\mathrm{W}$ & A & M & $\mathrm{W}$ & A & M & $\mathrm{W}$ & A & M & $\mathrm{W}$ \\
\hline \multicolumn{13}{|l|}{ Age } \\
\hline$\leq 20$ & $20 \quad(8)$ & $10(50)$ & $10(50)$ & 15 & 15 & 11 & 40 & 30 & 0 & 0.126 & 0.341 & 0.310 \\
\hline $21-60$ & $113(45)$ & $54(48)$ & $59(52)$ & 68 & 67 & 59 & 52 & 54 & 49 & & & \\
\hline$>60$ & $116(47)$ & $46(40)$ & $70(60)$ & 30 & 29 & 32 & 40 & 40 & 40 & & & \\
\hline \multicolumn{13}{|l|}{ Gender } \\
\hline Male & $110(44)$ & & & 41 & & & 46 & & & 0.390 & & \\
\hline Female & $139(56)$ & & & 45 & & & 45 & & & & & \\
\hline \multicolumn{13}{|l|}{ Nationality } \\
\hline Norwegian & $167(67)$ & $74(44)$ & $93(56)$ & 63 & NR & 57 & 51 & 57 & 42 & 0.011 & 0.030 & 0.145 \\
\hline Russian & $82(33)$ & $36(44)$ & $46(56)$ & 22 & 22 & 26 & 34 & 28 & 40 & & & \\
\hline \multicolumn{13}{|l|}{ Histological type } \\
\hline UPS & $68(27)$ & $35(51)$ & 33 (49) & 29 & 37 & 22 & 40 & 41 & 39 & 0.102 & 0.402 & 0.073 \\
\hline LMS & $67(27)$ & $14(20)$ & $53(80)$ & 45 & 26 & 48 & 46 & 43 & 47 & & & \\
\hline $\mathrm{LS}$ & 34 (14) & $18(53)$ & $16(47)$ & NR & NR & NR & 67 & 67 & 67 & & & \\
\hline MF/MFT & $20 \quad(8)$ & $7(35)$ & $13(65)$ & 43 & 43 & 120 & 50 & 38 & 54 & & & \\
\hline AS & 13 & $8(62)$ & $5(38)$ & 10 & 15 & 5 & 31 & 0 & 20 & & & \\
\hline RMS & $16(6)$ & $8(50)$ & $8(50)$ & 17 & 15 & 32 & 38 & 25 & 50 & & & \\
\hline MPNST & $11(5)$ & $5(45)$ & $6(55)$ & 49 & NR & 14 & 45 & 80 & 0 & & & \\
\hline SS & $16(6)$ & $11(69)$ & $5(31)$ & 31 & 31 & 31 & 29 & 34 & 20 & & & \\
\hline Other STS & 4 (2) & $4(100)$ & $0 \quad(0)$ & NR & 41 & 45 & 75 & 75 & - & & & \\
\hline \multicolumn{13}{|l|}{ Site } \\
\hline Extremities & $89(36)$ & $45(51)$ & $44(49)$ & 100 & 67 & 100 & 53 & 53 & 54 & 0.348 & 0.487 & 0.688 \\
\hline Trunk & $47(29)$ & $25(53)$ & $22(47)$ & 32 & 37 & 17 & 44 & 42 & 46 & & & \\
\hline Retroperitoneum & $37(25)$ & $15(41)$ & $22(59)$ & 25 & 21 & 36 & 38 & 31 & 42 & & & \\
\hline Head and neck & 18 (7) & $12(67)$ & $6(33)$ & 15 & 12 & 15 & 41 & 36 & 0 & & & \\
\hline Viscera & $58(23)$ & $13(22)$ & $45(78)$ & 30 & NR & 29 & 42 & 59 & 37 & & & \\
\hline \multicolumn{13}{|l|}{ Tumor size } \\
\hline$<5 \mathrm{~cm}$ & $74(30)$ & $33(45)$ & $41(55)$ & 127 & NR & 127 & 57 & 53 & 60 & 0.027 & 0.588 & 0.019 \\
\hline $5-10 \mathrm{~cm}$ & $91(37)$ & $38(42)$ & $53(58)$ & 44 & 41 & 45 & 45 & 47 & 44 & & & \\
\hline$>10 \mathrm{~cm}$ & $81(32)$ & $37(46)$ & $44(54)$ & 28 & 38 & 23 & 36 & 41 & 33 & & & \\
\hline Missing & 3 (1) & $2(67)$ & $1(33)$ & & & & & & & & & \\
\hline
\end{tabular}

Histological grade

1
2
3
Tumor depth

Superficial

Deep

Metastasis at the

time of diagnosis

Yes

No

NR NR 74

$41 \quad 45 \quad 45$

98 (39)

$41(42)$

$57(58)$

41

21

$15 \quad 26$

$17 \quad(7)$ 232 (93)

$10(59)$

7 (41) NR

NR NR 93 $\begin{array}{ll}40 & 30\end{array}$

470

$70 \quad 79$

45

25 
Table II. Continued.

\begin{tabular}{|c|c|c|c|c|c|c|c|c|c|c|c|c|}
\hline \multirow[b]{2}{*}{ Characteristic } & \multicolumn{3}{|c|}{ Patients, n (\%) } & \multicolumn{3}{|c|}{$\begin{array}{c}\text { Median survival } \\
\text { (months) } \\
\end{array}$} & \multicolumn{3}{|c|}{$\begin{array}{l}\text { 5-year survival } \\
(\%) \\
\end{array}$} & \multicolumn{3}{|c|}{ P-value } \\
\hline & A & M & $\mathrm{W}$ & A & $\mathrm{M}$ & W & A & M & $\mathrm{W}$ & A & M & $\mathrm{W}$ \\
\hline \multicolumn{13}{|l|}{ Surgery } \\
\hline Yes & $228(92)$ & $98(43)$ & $130(57)$ & 5 & 67 & 54 & 50 & 53 & 48 & $<0.001$ & $<0.001$ & $<0.001$ \\
\hline No & $21(8)$ & $12(57)$ & $9(43)$ & 59 & 5 & 4 & 0 & 0 & 0 & & & \\
\hline \multicolumn{13}{|l|}{ Resection margins } \\
\hline Free & $178(71)$ & $77(43)$ & $101(57)$ & 127 & NR & 75 & 66 & 64 & 51 & $<0.001$ & $<0.001$ & $<0.001$ \\
\hline Not free or no surg. & $71(29)$ & $33(46)$ & $38(54)$ & 10 & 10 & 10 & 18 & 0 & 28 & & & \\
\hline \multicolumn{13}{|l|}{ Chemotherapy } \\
\hline No & $191(77)$ & $88(46)$ & $103(54)$ & 52 & 67 & 48 & 47 & 51 & 44 & 0.424 & 0.023 & 0.396 \\
\hline Yes & $58(23)$ & $22(38)$ & $36(62)$ & 29 & 15 & 38 & 40 & 27 & 47 & & & \\
\hline \multicolumn{13}{|l|}{ Histological grade } \\
\hline \multicolumn{13}{|l|}{ Radiotherapy } \\
\hline No & $176(71)$ & $75(43)$ & $101(57)$ & 48 & 41 & 48 & 46 & 47 & 47 & 0.590 & 0.991 & 0.389 \\
\hline Yes & $73(29)$ & $35(48)$ & $38(52)$ & 38 & 41 & 22 & 43 & 45 & 42 & & & \\
\hline
\end{tabular}

Non-GIST STS, non-gastrointestinal stromal tumor soft-tissue sarcoma; A, all; M, men; W, women; UPS, undifferentiated pleomorphic sarcoma; LMS, leiomyosarcoma; LS, liposarcoma; MF/MFT, malignant fibroblastic/myofibroblastic tumors; AS, angiosarcoma; RMS, rhabdomyosarcoma; MPNST, malignant peripheral nerve sheath tumor; SS, synovial sarcoma; NR, not reached; NOS, not otherwise specified.

\section{Discussion}

Expression of ER and PgR is a routinely investigated indicator of endocrine therapy success in breast cancer $(12,13)$ and a modest, but significantly better overall survival of anti-estrogen receptor therapy is documented (14). ER and PgR are also reported to be positive prognosticators of leiomyosarcomas in uterus (18). However, extrauterine sarcomas have barely been explored in this context. The distribution and prognostic value of expression of these steroid hormone receptors in STSs are therefore of great scientific interest.

In our large-scale retrospective study, ER showed significantly favourable influence on survival in female patients, while $\mathrm{PgR}$ was an unfavourable prognosticator for men in the univariate analyses. The coexpression of $\mathrm{ER}^{-} / \mathrm{PgR}^{+}$was a significantly independent negative prognostic indicator of DSS. To our knowledge this is the first prognostic evaluation of these biomarkers in whole-array non-GIST STSs.

Steroid hormones, especially estrogens, but also progestins, are known to stimulate the progression of breast cancer as well as other gynaecological tumors. The expression of ER and $\mathrm{PgR}$, as docking sites for the corresponding hormones, can therefore serve as a predictor of tumor response to both surgical and medical endocrine therapy. For more than 3 decades, ER has been the most important biomarker measured for the management of breast cancer, due to considerable benefit of hormone-ablation therapy for ER-positive in contrast to ER-negative breast cancers $(12,13)$.
Due to possible toxicity and adverse effects of endocrine therapy it was essential to establish the cut-off point for ER and PgR expression. For ligand-binding assays (LBA) which was used until about early 1990s, this threshold value varied from 3 to $20 \mathrm{femtomol} / \mathrm{l}$. After the establishment of IHC methods, the corresponding value fluctuated between 1 and $10 \%$ positive cells $(17,19)$. Several studies showed that even low steroid hormone expression may subsequently have importance for endocrine therapy (20). The recent issued guideline recommendations by the American Society of Clinical Oncology/College of American Pathologists determine 1\% positivity as a cut-off value in breast cancer both for ER and PgR based on multiple clinical trials (21).

A diversity of soft tissue tumors express both ER and PgR $(22,23)$, but there is also uncertainty concerning steroid hormone receptor expression value in the mesenchymal tumors. Klemi et al showed effect of hormone-ablation therapy in aggressive intraabdominal fibromatosis (24). Leithner and colleagues found ER positivity in a minority of 80 fibromatosis patients, while PgR was invariably negative, and concluded that the published effects of antioestrogens in the treatment of aggressive fibromatoses may not be attributable to estrogen receptor (25). However, the established positivity cut-off in this study was $10 \%$, which could have distorted the result.

Leiomyomatous tumors of the uterus are most studied in the context of steroid hormone receptor expression. Generally, it is agreed that the rate of ER and PgR expression rises with the grade of differentiation of malignant tumors $(18,26)$. 
Table III. Hormone receptor expression grade in relation to clinicopathological variables in 249 non-GIST STSs.

\begin{tabular}{|c|c|c|c|c|c|c|c|c|}
\hline \multirow[b]{2}{*}{ Characteristic } & \multicolumn{4}{|c|}{$\mathrm{ER}^{\mathrm{a}}$} & \multicolumn{4}{|c|}{$\mathrm{PGR}^{\mathrm{a}}$} \\
\hline & $0(n=143)$ & $1(n=56)$ & $2(n=20)$ & $3(n=12)$ & $0(n=166)$ & $1(n=55)$ & $2(n=15)$ & $3(n=13)$ \\
\hline
\end{tabular}

Age

$\leq 20$

21-60

$>60$

14

61

5

24

68

27

$66 \quad 26$

77

30

87

56

43

13

1
11
8

11

9

19

Norwegian

Russian

Histological type

UPS

LMS

MF/MFT

AS

RMS

MPNST

SS

Other STS

$\begin{array}{rrr}39 & 16 & 7 \\ 36 & 11 & 4 \\ 21 & 7 & 3 \\ 13 & 4 & 1 \\ 8 & 4 & 2 \\ 7 & 6 & 1 \\ 9 & 1 & \\ 8 & 6 & 1 \\ 2 & 1 & \end{array}$

Site

Extremities

Trunk

Retroperitoneum

Head and neck

Viscera

56

25

26

8

28

$5-10 \mathrm{~cm}$

$>10 \mathrm{~cm}$

Histological grade

$$
1
$$

3

\section{0}

9

3

$$
\begin{array}{r}
9 \\
74
\end{array}
$$

83

81

85

12

12

0

110

56

49

41

26

11

12

7

8

9

3

6

21

18

23

22

30

15

10

5

11

2

Tumor depth

Superficial

Deep

12

131

$$
3
$$

53

\section{2}

18

0

12

15

151

44

64

58

46

60

57

62

30

27

11

36

$6 \quad 11$

11
18

16

16
13
7
3
6

\section{5}

3

3

1

2

4

0
10

Metastasis at the time of diagnosis

$$
\text { Yes }
$$

No

10

140

26

Surgery

No
Yes

$\begin{array}{rr}1 & 1 \\ 9 & 11\end{array}$

42 
Table III. Continued.

\begin{tabular}{|c|c|c|c|c|c|c|c|c|}
\hline \multirow[b]{2}{*}{ Characteristic } & \multicolumn{4}{|c|}{$\mathrm{ER}^{\mathrm{a}}$} & \multicolumn{4}{|c|}{$\mathrm{PGR}^{\mathrm{a}}$} \\
\hline & $0(n=143)$ & $1(n=56)$ & $2(n=20)$ & $3(n=12)$ & $0(n=166)$ & $1(n=55)$ & $2(n=15)$ & $3(n=13)$ \\
\hline \multicolumn{9}{|l|}{ Resection margins } \\
\hline Not free or no surgery & 36 & 15 & 8 & 2 & 39 & 18 & 6 & 2 \\
\hline Free & 107 & 41 & 12 & 10 & 127 & 27 & 9 & 11 \\
\hline \multicolumn{9}{|l|}{ Chemotherapy } \\
\hline No & 117 & 38 & 14 & 5 & 138 & 32 & 9 & 5 \\
\hline Yes & 26 & 18 & 6 & 7 & 28 & 13 & 6 & 8 \\
\hline \multicolumn{9}{|l|}{ Radiotherapy } \\
\hline No & 100 & 37 & 17 & 11 & 117 & 28 & 12 & 11 \\
\hline Yes & 43 & 19 & 3 & 1 & 49 & 17 & 3 & 2 \\
\hline
\end{tabular}

Non-GIST STS, non-gastrointestinal stromal tumor soft-tissue sarcoma; UPS, undifferentiated pleomorphic sarcoma; LMS, leiomyosarcoma; LS, liposarcoma; MF/MFT, malignant fibroblastic/myofibroblastic tumors; AS, angiosarcoma; RMS, rhabdomyosarcoma; MPNST, malignant

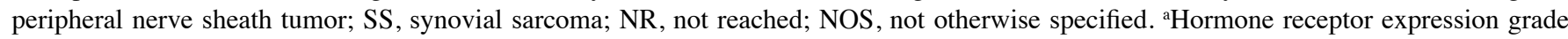
designated as: 0 , negative; 1 , weak; 2 , intermediate; 3 , strong.

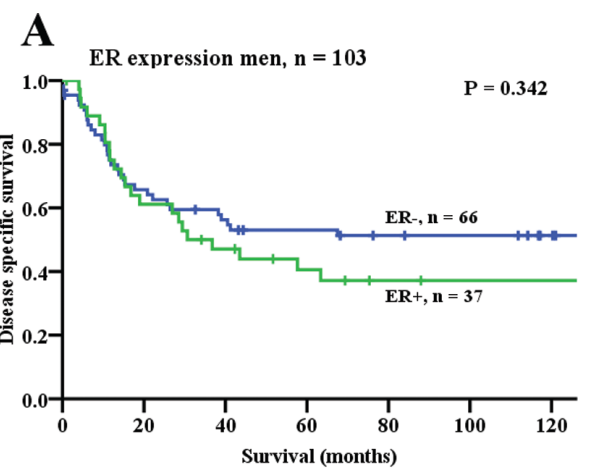

\section{B}
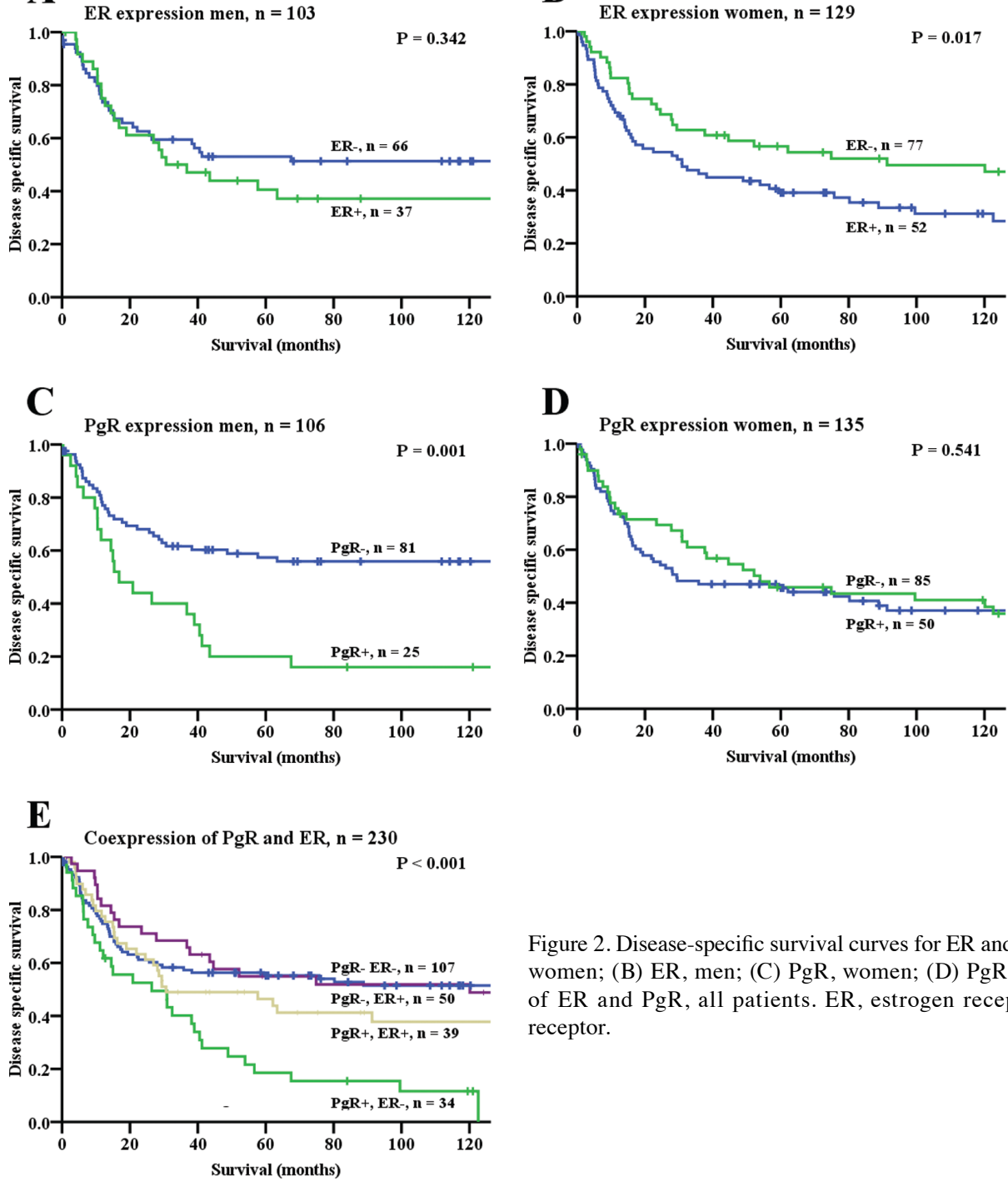

Figure 2. Disease-specific survival curves for ER and PgR expression. (A) ER, women; (B) ER, men; (C) PgR, women; (D) PgR, men; (E) Coexpression of ER and $\mathrm{PgR}$, all patients. ER, estrogen receptor; $\mathrm{PgR}$, progesterone receptor. 
Table IV. Tumor expression of ER and PgR and their prognostic impact on disease-specific survival in patients with non-GIST STSs (univariate analyses; log-rank test, $n=249$ ), for all patients, separately for men and women and for coexpression of ER and PgR.

\begin{tabular}{|c|c|c|c|c|c|}
\hline Characteristic & Patients (n) & Patients (\%) & Median survival (months) & 5-year survival (\%) & P-value \\
\hline \multicolumn{6}{|l|}{ ER, all patients } \\
\hline Negative & 143 & 57 & 41 & 46 & 0.333 \\
\hline Positive & 89 & 36 & 62 & 50 & \\
\hline Missing & 17 & 7 & & & \\
\hline \multicolumn{6}{|l|}{ ER, men } \\
\hline Negative & 66 & 60 & NR & 53 & 0.342 \\
\hline Positive & 37 & 34 & 31 & 41 & \\
\hline Missing & 7 & 6 & & & \\
\hline \multicolumn{6}{|l|}{ ER, women } \\
\hline Negative & 77 & 55 & 31 & 39 & 0.017 \\
\hline Positive & 52 & 37 & 91 & 57 & \\
\hline Missing & 10 & 8 & & & \\
\hline \multicolumn{6}{|c|}{ PgR, all patients } \\
\hline Negative & 166 & 67 & 63 & 51 & 0.079 \\
\hline Positive & 75 & 30 & 38 & 37 & \\
\hline Missing & 8 & 3 & & & \\
\hline \multicolumn{6}{|l|}{$\mathrm{PgR}$, men } \\
\hline Negative & 81 & 74 & NR & 57 & 0.001 \\
\hline Positive & 25 & 23 & 17 & 20 & \\
\hline Missing & 4 & 3 & & & \\
\hline \multicolumn{6}{|l|}{ PgR, women } \\
\hline Negative & 85 & 61 & 29 & 46 & 0.541 \\
\hline Positive & 50 & 36 & 54 & 46 & \\
\hline Missing & 4 & 3 & & & \\
\hline \multicolumn{6}{|c|}{$\begin{array}{l}\mathrm{ER} / \mathrm{PgR} \text { coexpression, } \\
\text { all patients }\end{array}$} \\
\hline ER $/$ PGR $^{-}$ & 107 & 43 & 127 & 55 & $<0.001$ \\
\hline $\mathrm{ER}^{-} / \mathrm{PgR}^{+}$ & 34 & 14 & 26 & 18 & \\
\hline $\mathrm{ER}^{+} / \mathrm{PgR}^{-}$ & 50 & 20 & 31 & 46 & \\
\hline $\mathrm{ER}^{+} / \mathrm{PgR}^{+}$ & 39 & 16 & 120 & 55 & \\
\hline Missing & 19 & 7 & & & \\
\hline
\end{tabular}

Non-GIST STS, non-gastrointestinal stromal tumor soft-tissue sarcoma; ER, estrogen receptor; PgR, progesterone receptor; NR, not reached.

However, the information concerning steroid hormone receptor expression in soft tissue tumors outside the gynaecological area is scarce and controversial. Indeed, the extent of ER and $\mathrm{PgR}$ expression shows a surprising discrepancy in different studies $(18,22,23,25)$. This may also be due to different cut-off points used by the authors. Most of the studies utilise established scoring system for breast cancer. Anyway, we do not know whether a scoring system elaborated for gynaeco- logical cancers, which are mostly ER and $\operatorname{PgR}$ positive, is valid in sarcomas.

We have modified the Allred score (17) for STSs and used $1 \%$ positivity as cut-off value. The strong and moderate (score 3 and 2, respectively) hormone receptor expression occurred mostly in sarcomas of uterus, pelvis and breast, while the weak (score 1) expression of both ER and PgR was surprisingly evenly distributed among location, gender and age. Generally, 
Table V. Results of the Cox regression analysis summarizing significant independent prognostic factors in the overall material.

\begin{tabular}{lccc}
\hline Factor & Hazard ratio & $95 \%$ CI & P-value \\
\hline $\begin{array}{l}\text { Tumor depth } \\
\text { Superficial }\end{array}$ & 1.0 & & \\
Deep & 12 & $1.7-88$ & 0.013 \\
Malignancy grade & & & \\
1 & 1.0 & & $<0.001^{\mathrm{a}}$ \\
2 & 2.9 & $1.7-5.1$ & $<0.001$ \\
3 & 3.3 & $1.9-6.0$ & $<0.001$
\end{tabular}

Metastasis at the

time of diagnosis

$\begin{array}{llll}\text { No } & 1.0 & & \\ \text { Yes } & 2.2 & 1.4-3.5 & 0.001\end{array}$

Surgery

Yes $\quad 1.0$

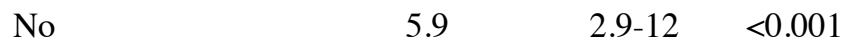

Resection-margins

Free $\quad 1.0$

$\begin{array}{llll}\text { Non-free } & 2.6 & 1.7-4.0<0.001\end{array}$

ER/PgR coexpression

$0.007^{\mathrm{a}}$

ER-PGR

1.0

ER-PGR ${ }^{+}$

1.9

1.2-3.1

0.008

$\mathrm{ER}^{+} \mathrm{PGR}$

1.4

0.86-2.3

0.183

$\mathrm{ER}^{+} \mathrm{PGR}^{+}$

0.73

0.43-1.3

0.938

UPS, undifferentiated pleomorphic sarcoma; MF/MFT, malignant fibroblastic/myofibroblastic tumors; MPNST, malignant peripheral nerve sheath tumor; NOS, not otherwise specified; ER, estrogen

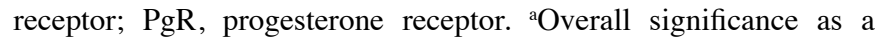
prognostic factor.

$36 \%$ of the tumors expressed ER and $30 \%$ expressed PgR in our material, which is partly in agreement with findings of Chaudhuri et al (22) who found ER to be positive in $24 \%$ of 29 investigated STS. PgR, however, was positive in just 1 of $29(4 \%)$ tumors in their cytosol assay-based study with a cut-off value 10 femtomol/l. In our study, ER expression had positive impact on survival in women in univariate analysis, but failed to show any significant value in the Cox proportional hazards analysis.

The prognostic value of $\mathrm{PgR}$ with regard to antiestrogen therapy effect is controversial (27), but the same criteria and positivity threshold for PgR as for ER is recommended (21). $\mathrm{PgR}$ expression is shown to have a positive prognostic impact in meningeomas (28). In our study, PgR expression showed a clearly negative impact on DSS in men and slightly positive, but not significant influence on survival in women.
The value of ER/PgR coexpression profiles is well studied in breast carcinoma. Shortly, any hormone receptor positivity gives better prognosis for success of antihormonal therapy $(29,30)$. We were not able to find any available published investigation of the prognostic impact of ER/PgR coexpression profiles on DSS and overall survival without relation to endocrine therapy. In our study, the $\mathrm{ER}^{-} / \mathrm{PgR}^{+}$profile was a significantly unfavourable factor for the whole patient cohort both in univariate and in multivariate analysis. Interestingly, such a profile occurred in only $2 \%$ of patients in one large-scale study, based on 3000 breast cancer cases (29), while in our STS study this profile was seen in $14 \%$ of the tumors.

In conclusion, we have characterized occurrence, distribution and prognostic value of ER and PgR in non-GIST STS. ER was a positive prognosticator in women, while PGR was a negative prognosticator in men. The $\mathrm{ER}^{-} / \mathrm{PgR}^{+}$profile was a negative prognosticator for the whole patient cohort. Pointing out aggressive phenotypes of sarcomas may help to identify patients who may have benefit from endocrine therapy.

\section{Acknowledgements}

We are grateful to Frode Skjold for coupling of databases, Magnus L. Persson for making the TMA blocks, Marit Nilsen and Siv B. Larsen for immunohistochemical staining. This study was funded by the Helse Nord, The Norwegian Childhood Cancer Network, The Norwegian Sarcoma Group and The Norwegian Cancer Society.

\section{References}

1. Gustafson P: Soft tissue sarcoma. Epidemiology and prognosis in 508 patients. Acta Orthop Scand (Suppl) 259: 1-31, 1994.

2. Engellau J, Anderson H, Rydholm A, et al: Time dependence of prognostic factors for patients with soft tissue sarcoma: a Scandinavian Sarcoma Group Study of 338 malignant fibrous histiocy tomas. Cancer 100: 2233-2239, 2004.

3. Dickinson IC, Whitwell DJ, Battistuta D, Thompson B, Strobel N, Duggal A and Steadman P: Surgical margin and its influence on survival in soft tissue sarcoma. ANZ J Surg 76: 104-109, 2006.

4. Zagars GK, Ballo MT, Pisters PW, Pollock RE, Patel SR and Benjamin RS: Prognostic factors for disease-specific survival after first relapse of soft-tissue sarcoma: analysis of 402 patients with disease relapse after initial conservative surgery and radiotherapy. Int J Radiat Oncol Biol Phys 57: 739-747, 2003.

5. Raney RB Jr, Crist WM, Maurer HM and Foulkes MA: Prognosis of children with soft tissue sarcoma who relapse after achieving a complete response. A report from the Intergroup Rhabdomyosarcoma Study I. Cancer 52: 44-50, 1983.

6. Kiatisevi P, Asavamongkolkul A, Phimolsarnti R, Waikakul S and Benjarassamerote $\mathrm{S}$ : The outcomes and prognostic factors of patients with soft-tissue sarcoma. J Med Assoc Thai 89: 334-342, 2006.

7. Yang RS, Lane JM, Eilber FR, et al: High grade soft tissue sarcoma of the flexor fossae. Size rather than compartmental status determine prognosis. Cancer 76: 1398-1405, 1995.

8. Mendenhall WM, Zlotecki RA, Hochwald SN, Hemming AW, Grobmyer SR and Cance WG: Retroperitoneal soft tissue sarcoma. Cancer 104: 669-675, 2005.

9. Koea JB, Leung D, Lewis JJ and Brennan MF: Histopathologic type: an independent prognostic factor in primary soft tissue sarcoma of the extremity? Ann Surg Oncol 10: 432-440, 2003.

10. Pelletier G: Localization of androgen and estrogen receptors in rat and primate tissues. Histol Histopathol 15: 1261-1270, 2000.

11. Giangrande PH, Kimbrel EA, Edwards DP and McDonnell DP: The opposing transcriptional activities of the two isoforms of the human progesterone receptor are due to differential cofactor binding. Mol Cell Biol 20: 3102-3115, 2000. 
12. Fisher B, Redmond C, Brown A, et al: Influence of tumor estrogen and progesterone receptor levels on the response to tamoxifen and chemotherapy in primary breast cancer. J Clin Oncol 1: 227-241, 1983.

13. Fisher B, Redmond C, Brown A, et al: Treatment of primary breast cancer with chemotherapy and tamoxifen. N Engl J Med 305: 1-6, 1981

14. Knight WA, Livingston RB, Gregory EJ and McGuire WL: Estrogen receptor as an independent prognostic factor for early recurrence in breast cancer. Cancer Res 37: 4669-4671, 1977.

15. Fletcher CDM, Unni KK and Mertens F (eds): World Health Organization Classification of Tumours. Pathology and Genetics of Tumours of Soft Tissue and Bone. Fletcher CDM UKKMF (ed). IARC Press, Lyon, 2002.

16. Bremnes RM, Veve R, Gabrielson E, et al: High-throughput tissue microarray analysis used to evaluate biology and prognostic significance of the E-cadherin pathway in non-small-cell lung cancer. J Clin Oncol 20: 2417-2428, 2002.

17. Harvey JM, Clark GM, Osborne CK and Allred DC: Estrogen receptor status by immunohistochemistry is superior to the ligandbinding assay for predicting response to adjuvant endocrine therapy in breast cancer. J Clin Oncol 17: 1474-1481, 1999.

18. Kelley TW, Borden EC and Goldblum JR: Estrogen and progesterone receptor expression in uterine and extrauterine leiomyosarcomas: an immunohistochemical study. Appl Immunohistochem Mol Morphol 12: 338-341, 2004.

19. Barnes DM, Harris WH, Smith P, Millis RR and Rubens RD: Immunohistochemical determination of oestrogen receptor: comparison of different methods of assessment of staining and correlation with clinical outcome of breast cancer patients. Br J Cancer 74: 1445-1451, 1996.

20. Rexhepaj E, Brennan DJ, Holloway P, et al: Novel image analysis approach for quantifying expression of nuclear proteins assessed by immunohistochemistry: application to measurement of oestrogen and progesterone receptor levels in breast cancer. Breast Cancer Res 10: R89, 2008.
21. Hammond ME, Hayes DF, Dowsett M, et al: American Society of Clinical Oncology/College of American Pathologists guideline recommendations for immunohistochemical testing of estrogen and progesterone receptors in breast cancer (unabridged version). Arch Pathol Lab Med 134: E48-E72, 2010.

22. Chaudhuri PK, Walker MJ, Beattie CW and Das Gupta TK: Distribution of steroid hormone receptors in human soft tissue sarcomas. Surgery 90: 149-153, 1981.

23. Weiss SW, Langloss JM, Shmookler BM, Malawer MM, D'Avis J, Enzinger FM and Stanton R: Estrogen receptor protein in bone and soft tissue tumors. Lab Invest 54: 689-694, 1986.

24. Klemi P, Alanen K, Hietanen S, Grenman S, Varpula M and Salmi T: Response of estrogen receptor-positive intraabdominal fibromatosis to aromatase inhibitor therapy. Obstet Gynecol 102: $1155-1158,2003$

25. Leithner A, Gapp M, Radl R, et al: Immunohistochemical analysis of desmoid tumours. J Clin Pathol 58: 1152-1156, 2005.

26. Bodner K, Bodner-Adler B, Kimberger O, Czerwenka K and Mayerhofer K: Estrogen and progesterone receptor expression in patients with uterine smooth muscle tumors. Fertil Steril 81: 1062-1066, 2004.

27. Hayes DF: Markers of endocrine sensitivity. Breast Cancer Res 10 (Suppl. 4): S18, 2008

28. Roser F, Nakamura M, Bellinzona M, Rosahl SK, Ostertag H and Samii M: The prognostic value of progesterone receptor status in meningiomas. J Clin Pathol 57: 1033-1037, 2004.

29. Bernoux A, De Cremoux P, Laine-Bidron C, Martin EC, Asselain B and Magdelenat H: Estrogen receptor negative and progesterone receptor positive primary breast cancer: pathological characteristics and clinical outcome. Institut Curie Breast Cancer Study Group. Breast Cancer Res Treat 49: 219-225, 1998.

30. Clark GM, McGuire WL, Hubay CA, Pearson OH and Marshall JS: Progesterone receptors as a prognostic factor in Stage II breast cancer. N Engl J Med 309: 1343-1347, 1983. 